\title{
Evaluation of University Libraries in Turkey within the Context of Cloud Computing
}

\author{
Hakan Aydin \\ Department of Computer Engineering, Faculty of Engineering and Architecture, \\ Istanbul Gelisim University, 34315, Avcilar - Istanbul, Turkey \\ E-mail: haaydin@gelisim.edu.tr
}

\begin{abstract}
Cloud computing is a service model that allows access to information resources such as computer networks, servers, databases and computer applications at any time and from anywhere. University libraries, like other libraries, already started to benefit from the cloud computing service model that provides benefits such as diversity, flexibility, continuity, scalability, and cost-effectiveness in their information services. In recent years, the increase in the number of universities has also increased the number of university libraries in Turkey. Cloud computing will enable university libraries, especially those with limited budgets, to provide information services more cost-effectively. In this study it is aimed to evaluate the position of university libraries in Turkey within the context of cloud computing. The structured interview technique was used in the research. SPSS program was used to evaluate the data. Percentage values, frequency and Chi-square statistic calculations were used to analyze the data. As a result of the research, the existing conditions and problems in the usage cloud service model in university libraries have been tried to be identified, a road map for solving these problems has been put into in this context.
\end{abstract}

Keywords: Cloud computing; Library services; Information services; University libraries

DOI: $10.7176 / \mathrm{JSTR} / 6-11-05$

\section{Türkiye'deki Üniversite Kütüphanelerinin Bulut Bilişim Bağlamında Değerlendirilmesi}

\begin{abstract}
Özet
Bulut bilişim, bilgisayar ağları, sunucular, veritabanları ve bilgisayar uygulamaları gibi bilgi kaynaklarına her zaman ve her yerden erişime izin veren bir hizmet modelidir. Üniversite kütüphaneleri, diğer kütüphaneler gibi, bilgi hizmetlerinde çeşitlilik, esneklik, süreklilik, ölçeklenebilirlik ve maliyet etkinliği gibi faydalar sağlayan bulut bilişim hizmet modelinden zaten yararlanmaya başladı. Son yıllarda üniversite sayısındaki artış, Türkiye'deki üniversite kütüphanesi sayısını da artırmıştır. Bulut bilişim, üniversite kütüphanelerinin, özellikle sınırlı bütçeye sahip olanların, bilgi hizmetlerini daha uygun maliyetli olarak sunmasını sağlayacaktır. Bu çalışmada, Türkiye'deki üniversite kütüphanelerinin bulut bilişim bağlamındaki konumunun değerlendirilmesi amaçlanmıştır. Araştırmada yapılandırılmış görüşme tekniği kullanılmıştır. Verilerin değerlendirilmesinde SPSS programı kullanılmıştır. Verilerin analizinde yüzde değerleri, frekans ve Kikare istatistik hesaplamaları kullanılmıştır. Araştırma sonucunda, üniversite kütüphanelerinde kullanım bulutu hizmet modelindeki mevcut koşullar ve sorunlar tespit edilmeye çalışılmış, bu sorunların çözümüne yönelik bir yol haritası bu kapsamda konulmuştur.
\end{abstract}

Anahtar Kelimeler: Bulut bilişim; Kütüphane hizmetleri; Bilgi hizmetleri; Üniversite kütüphaneleri 


\section{Giriş}

İlk üniversitelerin oluşumundan başlayarak üniversite yapılanması içinde yer alan kütüphaneler, üniversitelerin akademik faaliyetlerinde gereksinim duydukları her türlü bilgiyi herkese iletme konumunda ve zorunluluğunda olan başlıca bilgi merkezleridir (Çakın, 1998, s.40). Üniversite kütüphaneleri bilgi hizmetlerini kullanıcılarına sunma durumunda olan temel bilgi ve belge merkezleridir. Üniversitelerin, kütüphaneleri olmaksızın eğitim-öğretim ve araştırma faaliyetlerini sağlıklı bir şekilde yürütebilmelerini beklemek gerçekçi bir yaklaşım olmaz (Al, 2002, s.3). Üniversite kütüphaneleri bilgi teknolojisindeki gelişmeleri yakından izlemeli, bilgi kaynaklarını derleyerek bunlara erişim sağlamalı bilgi ve belge paylaşımı konusunda işbirliği içerisinde olmalıdırlar (Çukadar, 2011, s.3). Ancak zamanla kütüphaneler artan bilgi teknolojileri maliyetlerine karşıllk yeterli olmayan kütüphane bütçeleri ile karşı karşıya kalmışlardır. Artan maliyetler esas olarak yeni bilgisayar donanımları alınmasından, kütüphane otomasyon sistemlerine lisans ücreti ödenmesinden, bilgi sistemlerinin bakım ve onarımı, enerji ile nitelikli Bilgi ve İletişim Teknolojileri (BIT) personeli istihdamı masraflarından oluşmaktadır. Günümüzde kütüphanelerin BíT'e olan bağımlılı̆̆ı gün geçtikçe artmaktadır. Kütüphaneler BITT kaynaklarına her geçen gün daha fazla yatırım yapmaktadırlar. Kütüphaneler kendi faaliyetleri yanında ayrıca BİT kaynaklarının işletilmesi, bakımı, soğutması, sürüm güncellemesi, siber güvenlik faaliyetleri gibi emek, zaman ve personel gerektiren faaliyetleri de yürütmektedirler. Kütüphane BİT yatırımları yazılım, donanım, 1sıtma ve soğutma işlemleri dahil enerji maliyetlerini ve bilişim personeli gibi giderlere ayrılan operasyonel maliyetleri kapsamaktadır. Son yıllarda bu bağlamda özellikle BíT giderlerinde sağladığı maliyet etkinlik faydasından dolayı yeni bir hizmet modeli olan Bulut Bilişim Hizmet Modelinden faydalanılması gündeme gelmiştir. Bu model günümüzde adından sıkça söz ettiren, bilgi hizmetlerinde başta maliyet etkinlik olmak üzere çeşitlilik, esneklik, süreklilik ve ölçeklenebilirlik gibi faydalar sağlayan hizmet modelidir. Kütüphaneler bilgi hizmetlerini bulut bilişim hizmet modelinden faydalanılarak sunulmasına yönelik çalışmalar yapılmakta, bulut uygulamalarına bilgi hizmetlerinde yer vermekte ve kütüphane bulut uygulamaları çeşitlenerek artmaktadır. Günümüzde bulut bilişim hizmet modeli kısıtlı bütçelerine rağmen kütüphanelerin bilgi hizmetlerini maliyet etkin, çağdaş ve nitelikli olarak sunmalarına imkân sağlayan bilişim teknolojilerinden birisi haline gelmiştir.

Breeding'e (2012, s.11) göre, üniversite kütüphane hizmetlerinin sunulmasında bulut bilişimden yararlanılması hizmetlerden memnun olan kütüphane kullanıcı sayısının artıracaktır. Goldner'e (2011, s.4) göre bulut bilişim kütüphane iş akışlarını basitleştirirken kütüphanelere zaman ve paradan tasarruf etmelerine yardımcı olacaktır. Karadeniz ve Yılmaz (2016, s.78), bulut bilişimin kütüphanelerle ilişkisinin hem hazırlanacak strateji ve eylem planlarında yer alması gerektiğini, hem de bütün kütüphanelerin şimdiden hazırlık niteliğinde çalışmalara başlamaları gerektiğgini, halk kütüphanelerinin katalog kayıtlarının bulut üzerine aktarıldığını, benzer bilimsel ve uygulamalı çalışmaların yapabileceğini ifade etmektedir. Günümüzde bulut bilişim gelişmekte olan bir konu olmakla birlikte kütüphanelere yansımaları henüz emekleme safhasında olup zamanla kütüphanelerdeki layık olduğu yerini alacaktır (Kumar ve diğerleri, 2014, s.6). Çă̆ımız kütüphane kullanıcılarının beklentilerine paralel olarak bulut bilişim hizmet modelinden kütüphanelerde faydalanılması gün geçtikçe önemini artırmaktadır. Mali kaynaklarının büyük kısmı ile elektronik bilgi kaynaklarına yatırım yapan kütüphaneler bulut bilişimden daha fazla yararlanmak durumundadırlar (Akbaytürk ve diğerleri, 2014, s.2). Bu çerçevede araştırmada, Araştırmada, Türkiye üniversite kütüphaneleri konumunun bulut bilişim bağlamında değerlendirmek, bu doğrultuda bilgi hizmetlerinin buluta taşınması ve yapılandırılması konularında durum saptaması yapmak, sorunların neler olduğunu ortaya koymak ve bu sorunların çözümüne dönük bir yol haritası çıkarmak amaçlanmıştır.

\section{2. Üniversite Kütüphaneleri ve Bulut Bilişim Hizmet Modeli}

Bulut bilişim; isteğe bağlı hizmet, geniş ağ erişimi, ortak kaynak havuzu, esneklik ve ölçülebilir hizmet özellikleri bulunan ve "Bulut Kullanıcısı", "Bulut Denetleyicisi", "Bulut Servis Sağlayıcısı", "Bulut Aracısı" ve "Bulut Taşıyıcısı" bileşenleri bulunan bir hizmet modelidir (National Institute of Standards and Technology, 2011, s.19). Bulut bilişim, bilişim kaynaklarının maliyet etin olarak hizmete sunulmasına imkân veren, kullanıcıların söz konusu kaynaklara zaman ve mekân bağımsız olarak kullandığın kadar öde yöntemiyle erişebilmelerime olanak sağlayan yeni bir hizmet modelini ifade etmektedir. Bulut bilişimin; "Uygulamaların Hizmet Olarak Sunulması (UHOS)", "Ortamın Hizmet Olarak Sunulması (OHOS)" ve "Altyapının Hizmet Olarak Sunulması (AHOS)" olmak üzere üç temel hizmet modeli mevcuttur. AHOS yazılım ve donanım satın almaktan kaçınmayı, UHOS yazılım geliştirme, bakım, yönetim ve donanım ücretlerinin düşürülmesini amaçlamaktadır (Türk Standardları

$\mathbf{4 2} \mid \mathrm{P}$ a g e

www.iiste.org 
Enstitüsü, 2013, s.9). OHOS bulut kullanıcılarına platform altyapısında kontrol ve yönetim imkânı sunmaktadır. Bulut bilişim konumlandırma modelleri arasında; "Özel Bulut”, "Genel Bulut”, "Topluluk Bulutu" ve "Karma Bulut" modelleri sayılabilir (National Institute of Standards and Technology, 2011, ss.1-4).

"Gmail", "Wikipedia", "Hotmail" veya "Twitter" gibi bir web uygulamasını kullanmış olanların bulut bilişime ilişkin bir tecrübeleri var demektir (Mirashe ve Kalyankar, 2010, s.1). Üniversite kütüphaneleri "Google", "Facebook", "Flikr", "Side Share", "Social Book", "Amazon" gibi web uygulamalarını çoktan kullanmaya başlamışlardır (Dhamdhere, 2014, s.152). Bu bağlamda kütüphanelerin özellikle bulutta hizmet veren pek çok Web 2.0 teknolojisini kullanıyor olmaları nedeniyle bulut bilişimi kullanmaya başladıklarını söylemek mümkündür. Zimmer (2015, s.1), halk kütüphanelerinin teknolojik ihtiyaçlarını karşılayabilmek ve kullanıcılarına daha iyi bilgi hizmetleri sunabilmek maksadıyla artan oranlarda maliyet tasarrufu, esneklik ve gelişmiş veri yönetimi avantajlarından faydalanabilmek için bulut bilişim çözümlerine yöneldiklerini belirtmektedir. Bulut bilişim kullanan bilgisayarların düşük kapasiteli sabit diske, belleğe ve işlemciye sahip olması düşük donanım maliyetini de beraberinde getirmektedir (Çetiner, 2014). Bulut sanallaştırma teknolojileri sayesinde müşteri taleplerinin istenilen ölçüde karşılanabilmesi mümkündür (Okutucu, 2012, s.54). Bulut bilişim esnekliği ile kaynaklar hızlı ve esnek bir şekilde elde edilebilirken hızlı ve otomatik bir şekilde ölçeklenebilmektedir (Çam, 2012, s.36). Bulut bilişimin sunduğu en önemli avantajlardan biri olan esneklik; altyapının ihtiyaca göre daralıp genişleyebilmesi ve bu esnada hizmet sağlayıcının herhangi bir müdahalesine gerek duyulmaması olarak tanımlanabilir (Özdaş, 2014, s.33). İşletmelerin BİT altyapılarında karbon izini azaltmak istedikleri bir çağda "yeşil kimlik" bilgileri ile öne çıkmak isteyen büyük BİT altyapıları için bulut bilişim bu imkânı sağlamaktadır (Eyüpoğlu, 2013, s.45). Bulut teknolojileri kütüphaneler arasında daha fazla işbirliğini mümkün hale getirecektir (Kumar ve Mandal, 2013, s.400).

OCLC katalog paylaşım sistemi olan "World Cat" uygulaması kütüphanelerin bulut bilişimden faydalanılmasında verilebilecek en güzel örneklerden birisidir (Kaushik ve Kumar, 2013, s.272). OCLC'nin "WorldCat" katalog uygulaması ilk defa bulut bilişimin kütüphanelerde kullanımına bir örnektir (Yuvaraj, 2013, s.13). Kütüphaneler CD/DVD gibi elektronik ortamdaki pek çok içeriği buluta koyarak kullanıcıların veya araştırmacıların hizmetine sunabilirler (Gosavi ve diğerleri, 2012, s.57). Danışma hizmetlerinde geleneksel yöntemler yerine bulut tabanlı uygulamaların kullanılması daha iyi bir danışma hizmeti sağlayacak, kullanıcı memnuniyeti artacaktır (Tavluoğlu ve Korkmaz, 2014, s.294). Bulut bilişimin üniversite kütüphanelerine sağlayacağı faydalar arasında; bilgi teknolojileri maliyetlerinin azaltılması başta olmak üzere bilgi hizmetlerinde çeşitlilik, esneklik, süreklilik ve ölçeklenebilirlik, teknolojik ilerleme, veri depolama, topluluk gücü, erişilebilirlik, taşınabilirlik, çevrimiçi katalog (OPAC) bulutu oluşturma sayılabilir (Abdu ve diğerleri, 2017, ss.82-88; Goldner, 2011, ss.7-11; Gosavi ve diğerleri, 2012, s.58; Kumar ve diğerleri, 2014, s.6).

Bulut bilişim hizmet modeli faydalarının yanında bazı sorunları da beraberinde getirmektedir. Bulut bilişimde bilgi güvenliği, bilginin bulutta ilgili ya da yetkili kişilerce güvenli bir yolla ulaşılabilir ve kullanılabilir durumda olmasını gerektirmektedir (Külcü ve Henkoğlu, 2013, s.82). Bulut bilişimde ana iletişim mekanizması olarak internetin kullanılması ve verinin barındırıldı ̆̆ 1 konumun kontrol edilemiyor olması, veri mahremiyetine ilişkin çekincelerin artmasına sebep olmaktadır (Özdaş, 2014, s.40). Bulut bilişim hizmetlerinin aynı anda birçok kullanıcı tarafından kullanılması ve fiziksel kaynakların tüm kullanıcılar tarafından ortak olarak kullanılıyor olması, veri gizliliği ve güvenliği için riskler barındırmaktadır (Çetiner, 2014, s.62). Bulut bilişimin üniversite kütüphanelerinde kullanımının olası sorunları arasında; veri güvenliği/gizliliği, entelektüel mülkiyet hakları, standartlar, uygulamaların birlikte çalışabilirliği, internet bağlantısı, bulut yazılımları ve karmaşıklık sayılabilir (Abdu ve diğerleri, 2017, ss.82-88; Bala, 2012, s.2; Hwang ve diğerleri, 2012, s.205; Gokul ve Ambili, 2014, s.6; Kumar ve diğerleri, 2014, s.6;). Bulut bilişimin üniversite kütüphanelerinde kullanım alanları arasında; bulut tabanlı kütüphane otomasyon sistemleri, web siteleri, arama, veri depolama, dijital kütüphane, elektronik bilgi kaynakları, toplu kataloglar, danışma hizmetleri, bilgi paylaşımı, koleksiyon geliştirme, ödeme/ücretlendirme uygulamalar1 sayılabilir (Dhamdhere, 2014, ss.152-158; Gokul ve Ambili, 2014, s.23; Kaushik ve Kumar, 2013, s.272; Kumar ve Mandal, 2013, s.3).

Yuvaraj (2013, s.4) tarafından Hindistan'daki üniversite kütüphanelerinde yapılan araştırmaya göre kütüphanelerin büyük çoğunluğu "OCLC", "ExLibris", "Duraspace" ve "KB+" gibi bulut tabanlı kütüphane hizmetlerini kullanmaya başlamışlardır. Günümüzde kütüphane yazılım firmaları kütüphane otomasyon programlarını bulut tabanlı olarak üretmeye ve pazarlamaya başlamışlardır (Ertürk ve İles, 2015, s.1). Bulut bilişim teknolojisinin kullanılmaya başlanması ile birlikte yeni nesil olarak adlandırabileceğimiz bulut tabanlı kütüphane otomasyon sistemleri gündeme gelmiştir. Maliyet

43 | P a g e

www.iiste.org 
fiyatlarını azaltmak için kütüphaneler konsorsiyumlar kapsamında ortak kütüphane otomasyonu satın almak ve işletmek yerine ortak olarak "Paylaşılan Kütüphane Otomasyonu (shared ILS)" kullanmak istemektedirler (Vaughan ve Costello, 2011, s.1). Kütüphaneler yeni nesil kütüphane otomasyonlarını da bulut bilişim ortamında kullanmak istemektedirler (Breeding, 2012, s.30). "VTLS OpenSkies", "Serials Solutions Intota", "Ex Libris Alma", "OCLC WorldShare", "Innovative Interfeces Sierra", "Kuali OLE", "ProQuest Summons ve Intota 2", "III Siearra", "LibLime KOHA", "Sirsidynix BLUEcloud LSP" ve "EBSCO EDS" bulut tabanlı kütüphane otomasyon sistemlerine örnek olarak verilebilir (Grant, 2012, s.13; Ertürk ve ILES, 2015, s.2). Yuvaraj (2013, s.4) tarafindan yapilan araştırma sonuçları, kütüphanelerin "OCLC", "ExLibris", "Duraspace" ve "KB+" gibi bulut tabanlı kütüphane hizmetlerini kullandıklarını ortaya koymaktadır. Yeni nesil kütüphane otomasyon sistemlerinden birisi olan "Ex Libris Alma" yazılımı bulut tabanlı kütüphane otomasyon yazılımlarına bir örnek olarak gösterilebilir. "Ex Libris Alma", sağlama, basılı kaynak yönetimi, elektronik kaynak yönetimi, veri yönetimi, kataloglama, işbirliği hizmetleri ve "OpenURL" özelliklerini desteklemektedir (Grant, 2012, s.11). Örneğin Londra'daki Kingston Üniversitesi sahip olduğu elektronik ve basilı kaynaklarının yönetimini bulut tabanlı otomasyon sistemi olan "Alma" kütüphane otomasyon programı ile yapmaktadır (Gokul ve Ambili, 2014, s.6). Yine bulut tabanlı "Kuali" otomasyonu, Leigh Üniversite Kütüphanesi ve Chicago Üniversite Kütüphanesi 2013 yıllnda ilk olarak kullanan bulut tabanlı kütüphane otomasyonları arasindadır (Clift, 2012, s.4).

Kütüphaneler için bulut tabanlı hizmetlere örnekler Tablo 1'de yer almaktadır.

Tablo 1. Bulut Bilişimin Kütüphanelerde Kullanılabilecek Alanları

\begin{tabular}{|l|l|l|}
\hline \multicolumn{1}{|c|}{ Platform } & \multicolumn{1}{|c|}{ Sistemler } & \multicolumn{1}{c|}{ Örnekler } \\
\hline UHOS Uygulamaları & $\begin{array}{l}\text { OpenURL Link Çözümleyiciler, } \\
\text { Araştırma Rehberleri, Çevrimiçi } \\
\text { Danışma, Sunucu Sanallaştırma, Yük } \\
\text { Paylaşımı }\end{array}$ & $\begin{array}{l}\text { Google Uygulamaları, } \\
\text { OpenID, Salesforce.com, } \\
\text { Adobe, Microsoft }\end{array}$ \\
\hline OHOS Uygulamaları & $\begin{array}{l}\text { Bütünleşik Kütüphane Sistemleri, } \\
\text { Kütüphaneler Arası Ödünç Verme } \\
\text { Sistemi, Telif Hakk1 }\end{array}$ & $\begin{array}{l}\text { Akamai, Microsoft Azure, } \\
\text { Zoho, NetSuite, Facebook } \\
\text { Platform }\end{array}$ \\
\hline AHOS Uygulamaları & $\begin{array}{l}\text { Keşif Sistemleri, Dijital Depolama, } \\
\text { Arşiv Yönetimi, Web Siteleri, } \\
\text { Kurumsal Depolama }\end{array}$ & $\begin{array}{l}\text { Amazon Elastic Compute } \\
\text { Cloud (EC2), IBM, } \\
\text { Rackspace, TCS, } \\
\text { OpenNebula }\end{array}$ \\
\hline
\end{tabular}

Kaynak: Shaw, 2013

Bulut bilişimin kütüphanelerde kullanım örnekleri arasında; Arizona Üniversitesi Kütüphanesi çalı̧̧maları, Çin Akademik Kütüphaneleri tarafindan yürütülen "CALIS Projesi", "HathiTrust" Konsorsiyumu bulut çalışmaları, Kaliforniya Devlet Üniversitesi Kütüphanesi bulut çalışmaları, Kentucky Üniversitesi Kütüphanesi bulut çalışmaları, Kolombiya Halk Kütüphanesi bulut çalışmaları, "LibraryThing" bulut web sayfası, "LoCloud" İyi Uygulama Bulut Ağı Projesi, Mysore Üniversitesi Kütüphanesi bulut çalışmaları, Nijerya Üniversiteleri bulut çalışmaları, "Orbis Cascade Alliance" bulut çalı̧̧maları ve Çevrimiçi Bilgisayar Kütüphanesi Merkezi Paylaşılan Yönetim Hizmetleri (OCLC) bulut çalı̧̧maları sayılabilir (Bala, 2012, s.2; Hwang ve diğerleri, 2012, s.205; Ogbu ve Lawal, 2013, s.479; Han, 2011, s.205; Shaw, 2013, s.166; Ogbu ve Lawal, 2013; Wang, 2012, s.1).

\section{3. Çalışmanın Amacı, Kapsamı ve Yöntemi}

Araştırmanın amac1, Türkiye üniversite kütüphaneleri bilgi hizmetlerinin buluta taşınması ve yapılandırılması konularında durum saptaması yapmak, bu bağlamda sorunların neler olduğunu ortaya koymak ve bu sorunların çözümüne dönük çeşitli düzeylerdeki sorunların tanımlanması ve bu sorunların çözümüne dönük bir yol haritası çıkarmak olarak belirlenmiştir. Araştırmada kütüphane hizmetlerinin bulut ortamına taşınmasında son derece önemli olan aşağıdaki sorulara yanıt aranmıştır.

44 I P a g e

www.iiste.org 
o Türkiye üniversite kütüphanelerinin bulut bilişim konusundaki farkındalıkları nedir?

o Kütüphane hizmetlerinin buluta taşınmasına ilişkin gereksinim var mıdır?

o Kütüphanelerin sahip oldukları teknolojik olanaklar yeterli midir?

o Öncelikle bulut ortamına taşınması istenilen kütüphane hizmetleri nelerdir?

o Kütüphane hizmetlerinin bulut ortamına aktarılmasında karşılaşılabilecek olası sorunlar nelerdir?

Araştırmada betimleme yöntemi kullanılmıştır. Kaptan (1995, s. 59) bu yöntemi, olayların, grupların, kurumların vb. çeşitli alanların ne olduğu ve bu sırada gerçekleşen eylemleri daha iyi anlayabilme, aktarabilme adına aralarındaki ilişkinin açıklandığı bir unsur olarak görmektedir. Araştırmada veri toplama aracı olarak yapılandırılmış görüşme tekniğinden yararlanılmıştır. Araştırmada yer alan ve araştırmaya katılan üniversite kütüphanelerine yöneltilen sorulara ilişkin dağılım Tablo 2'de yer almaktadır. Araştırma soruları kapalı uçlu (Evet, Hayır), açık uçlu ve 5'li likert ölçeğinde hazırlanmış sorulardan oluşturulmuştur.

Tablo 2. Araştırmanın Soru Dağılımı

\begin{tabular}{l|l|l}
\hline \multicolumn{1}{c|}{ Soru Dağılımı } & \multicolumn{1}{c|}{$\mathrm{n}$} & \multicolumn{1}{c}{$\%$} \\
\hline Bulut Bilişim Farkındalığı & 4 & 16,6 \\
\hline Bulut Bilişim Gereksiniminin Varlığı ve Düzeyi & 1 & 4,3 \\
\hline Bulut Bilişim Uygulamalarının Kullanım Durumu & 4 & 16,6 \\
\hline Bulut Bilişime Geçiş Hazırlık Durumu ve Düzeyi & 10 & 41,6 \\
\hline Bulutta Sunulan Kütüphane Hizmetleri & 1 & 4,3 \\
\hline Bulut Bilişime Geçiş Fayda ve Sorunları & 4 & 16,6 \\
\hline Toplam & 24 & 100,0 \\
\hline
\end{tabular}

Bulguların değerlendirilmesinde "Statistical Package for the Social Sciences" (SPSS) programı kullanılmıştır. Verilerin tamamı bilgisayar ortamına aktarılmış ve sayısal verilerin analizinin tümü bilgisayar yoluyla yapılmıştır. Verilerin analizinde yüzdelik değerler, sıklık ve Ki-kare istatistik hesapları kullanılmıştır ve elde edilen sonucunda gerekli yorumlar yapılmıştır. Yapılandırılmış görüşme rehberinin hazırlanmasında, öncelikle Hacettepe Üniversitesi, Ortadoğu Teknik Üniversitesi ve Gazi Üniversitesi "Kütüphane ve Dokümantasyon Daire Başkanlıkları" ile çalışmanın yapılandırılması ve ön testi için görüşülmüştür. Aynı zamanda soruların oluşturulma aşamasında ve oluşturulduktan sonra ön test uygulanmış, çalışma için geri dönüş alınıp gerekli düzeltmeler ve eklemeler yapılmak suretiyle sorulara son hali oluşturulmuştur. Araştırmanın evrenini Türkiye Üniversite Kütüphaneleri oluşturmaktadır (Tablo 3). Türkiye üniversite kütüphaneleri araştırmaya \%71,5 oranında (126 kütüphane) katılım sağlamışlardır. Devlet üniversite kütüphaneleri \%80,7 (84 kütüphane) ile araştırmaya katılım sağlarken, vakıf üniversite kütüphaneleri \%58,3 (42 kütüphane) ile katılım sağlamıştır.

Tablo 3. Araştırmanın Evreni ve Örneklemi

\begin{tabular}{lll|lcl|lll}
\hline \multicolumn{3}{c|}{ Devlet Üniversiteleri } & \multicolumn{3}{c|}{ Vakıf Üniversiteleri } & \multicolumn{3}{c}{ Toplam } \\
\hline $\mathrm{M}$ & $\mathrm{N}$ & $\%$ & $\mathrm{M}$ & $\mathrm{N}$ & $\%$ & $\mathrm{M}$ & $\mathrm{N}$ & $\%$ \\
\hline 104 & 84 & 80,7 & 72 & 42 & 58,3 & 176 & 126 & 71,5 \\
\hline
\end{tabular}

(M)Mevcut, (N)Araştırmaya Katılım Sağlayanlar.

\section{Bulgular}

\subsection{Farkındalık Düzeyi}

Kütüphaneler bulut bilişim bilgi düzeylerine ilişkin soruya en yüksek oranda \%37,3 oranı ile "orta" düzey olarak yanıt vermişlerdir (Tablo 4). Araştırmaya katılım sağlayan kütüphanelerden sayıları az olsa da $(\% 4,8)$ bulut bilişimden hiç haberi olmayan kütüphanelerin varlığı dikkat çekicidir. 
Tablo 4: Bulut Bilişim Bilgi Düzeyi

\begin{tabular}{l|l|l}
\hline \multicolumn{1}{c|}{ Bilgi Düzeyi } & \multicolumn{1}{c|}{$\mathrm{n}$} & \multicolumn{1}{c}{$\%$} \\
\hline Çok iyi & 6 & 4,8 \\
\hline İyi & 34 & 27,0 \\
\hline Orta & 47 & 37,3 \\
\hline Zayif & 21 & 16,7 \\
\hline Bilgi sahibi değilim. & 18 & 14,2 \\
\hline Toplam & 126 & 100,0 \\
\hline
\end{tabular}

Katılımcıların bulut bilişim bilgi düzeylerinin yeterli olarak düşünülebileceği "çok iyi” ve "iyi" seçeneklerinin toplamıyla diğer seçenekler arasındaki farklılık Grafik 1'de yer almaktadır. Elde edilen veriler Türkiye üniversite kütüphanelerinin çoğunluğunun $(\% 68,2)$ bulut bilişim farkındalığının yeterli düzeyde olmadığını ortaya koymaktadır. Sayıları az olsa da (18 Adet) bulut bilişimden hiç haberi olmayan kütüphanelerin varlığı dikkat çekicidir. Devlet ve vakıf üniversite kütüphaneleri arasında bilgi düzeyinde anlamlı bir fark olup olmadığını belirlemek için yapılan ki-kare testinde anlamlı bir fark $(\chi 2=0,180)$ bulunamamıştır.

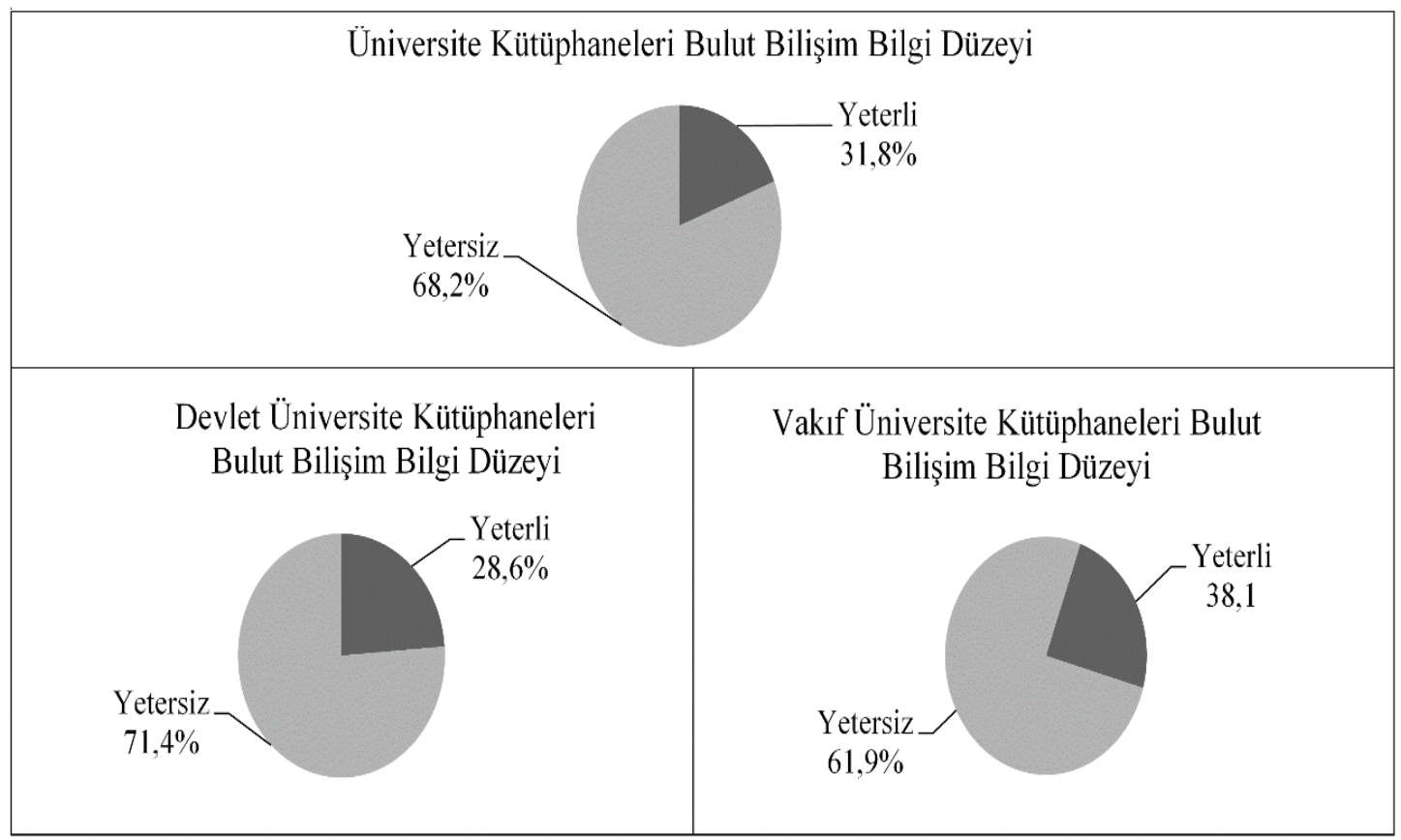

Şekil 1. Türkiye Üniversite Kütüphaneleri Bulut Bilişim Farkındalığı

Araştırmaya katılım sağlayan kütüphanelerin yaklaşık üçte birsi \%31,6 oranı ile bulut bilişim bilgisini öncelikle "literatürden" edindiklerini belirtmişlerdir (Tablo 5). Kütüphanelerin bulut bilişim bilgisini üst yönetimden edinme oranlarının diğer bilgi edinme ortamlarına nazaran oldukça düşük sayılabilecek bir düzeyde olması $(\% 1,8)$ dikkat çekicidir. $\mathrm{Bu}$ durum bilgi edinme ortamlarından yeterince yararlanılmadığı ortaya koymakta, aynı zamanda farkındalığın yeterli düzeyde olmadığını da desteklemektedir. Devlet ve vakıf üniversite kütüphanelerine göre bilgi edinme ortamları arasında anlamlı bir fark olup olmadığını belirlemek için yapılan ki-kare testinde "literatür" $(\chi 2=0,439)$, "seminer" $(\chi 2=0,280)$, "meslektaşlar" $(\chi 2=0,251)$, "firma" $(\chi 2=0,216)$ ve "üst yönetim" $(\chi 2=0,312)$ konularında anlamlı bir fark bulunamamıştır. 
Tablo 5. Bulut Bilişim Bilgi Edinme Ortamları

\begin{tabular}{l|l|l}
\hline \multicolumn{1}{c|}{ Bilgi Edinme Ortami } & \multicolumn{1}{|c|}{$\mathrm{n}$} & \multicolumn{1}{c}{$\%$} \\
\hline Literatür & 69 & 31,6 \\
\hline Seminer\&Konferans & 60 & 27,6 \\
\hline Meslektaşlar & 43 & 19,8 \\
\hline Firma & 42 & 19,2 \\
\hline Üst yönetim & 4 & 1,8 \\
\hline Toplam & 218 & 100,0 \\
\hline
\end{tabular}

Kütüphanelerin yarısından fazlası $(\% 60,2)$ ulusal çalışmaları, yaklaşık dörtte üçü $(\% 71,3)$ uluslararası çalışmaları takip etmediklerini belirtmişlerdir (Tablo 6). Elde edilen bulgular Türkiye üniversite kütüphanelerinin hem ulusal ve hem de uluslararası düzeydeki çalışmaları yeterli düzeyde takip etmediklerini ortaya koymaktadır. Devlet ve vakıf üniversite kütüphanelerine göre bulut çalışmalarının takibinde anlamlı bir fark olup olmadığını belirlemek için yapılan ki-kare testinde ulusal $(\chi 2=0,102)$ ve uluslararası $(\chi 2=0,138)$ çalışmaların takibinde anlamlı bir fark bulunamamıştır.

Tablo 6: Bulut Bilişim Çalışmaları Takibi

\begin{tabular}{l|l|l|l}
\hline \multicolumn{1}{c|}{ Değişkenler } & \multicolumn{1}{|c|}{ Değişken Düzeyi } & \multicolumn{1}{c}{$\mathrm{n}$} & \multicolumn{1}{c}{$\%$} \\
\hline \multirow{4}{*}{ Ulusal Çalışmaların Takibi } & Takip ediyorum. & 43 & 39,8 \\
\cline { 2 - 4 } & Takip etmiyorum. & 65 & 60,2 \\
\cline { 2 - 4 } & Toplam & 108 & 100,0 \\
\hline \multirow{4}{*}{ Uluslararası Çalışmaların Takibi } & Takip ediyorum. & 31 & 28,7 \\
\cline { 2 - 4 } & Takip etmiyorum. & 77 & 71,3 \\
\cline { 2 - 4 } & Toplam & 108 & 100,0 \\
\hline
\end{tabular}

\subsection{Gereksinimin Varlı̆̆}

Kütüphanelerin yaklaşık dörtte üçü $(\% 74,6)$ bütçelerinin yüksek maliyet oluşturan kalemleri arasında en yüksek harcama kalemi olarak "yazılım” harcamalarını gördüklerini belirtmişlerdir (Tablo 7). Bu durumu \%71,0 ile "donanım", \%61,1 ile "işletme", \%57,9 ile "elektrik" ve \%50,8 ile "personel" harcamaları izlemektedir. Araştırmamızda elde edilen BİT maliyetlerinin genelde bütçelerin yüksek maliyet oluşturan kalemleri arasında görülmesi durumu kütüphanelerde bulut bilişime olan gereksinimin bir göstergesi olarak değerlendirilebilir. Kütüphanelerin en yüksek harcama kalemi olarak "yazılım" harcamalarını belirtmeleri durumu öncelikle UHOS bulut hizmetlerine olan gereksinimin bir göstergesi olarak öngörülebilir. Devlet ve vakıf üniversite kütüphanelerine göre BİT harcama değerlendirmelerinde anlamlı bir fark olup olmadığını belirlemek için yapılan ki-kare testinde, işletme $(\chi 2=0,349)$, elektrik $(\chi 2=0,117)$, yazılım $\left(\chi^{2}=0,590\right)$, donanım $\left(\chi^{2}=0,285\right)$ ve personel $(\chi 2=0,108)$ harcamalarında anlamlı bir fark olmadığı anlaşılmıştır.

Tablo 7. BİT Harcamaları

\begin{tabular}{|c|c|c|c|c|c|c|c|c|}
\hline \multirow{2}{*}{ Değişkenler } & \multicolumn{2}{|c|}{ Yüksek değil } & \multicolumn{2}{|c|}{ Kararsızım } & \multicolumn{2}{|c|}{ Yüksek } & \multicolumn{2}{|c|}{ Toplam } \\
\hline & $\mathrm{n}$ & $\%$ & $\mathrm{n}$ & $\%$ & $\mathrm{n}$ & $\%$ & $\mathrm{n}$ & $\%$ \\
\hline İşletme & 24 & 19,0 & 25 & 19,8 & 77 & 61,2 & 126 & 100,0 \\
\hline Elektrik & 28 & 22,2 & 25 & 19,8 & 73 & 58 & 126 & 100,0 \\
\hline Yazılım & 17 & 13,5 & 15 & 11,9 & 94 & 74,6 & 126 & 100,0 \\
\hline Donanım & 26 & 21,0 & 10 & 8,0 & 88 & 71,0 & 126 & 100,0 \\
\hline Personel & 27 & 21,4 & 35 & 27,8 & 64 & 50,8 & 126 & 100,0 \\
\hline
\end{tabular}




\subsection{Bulut Bilişim Uygulamalart}

Kütüphanelerin oldukça düşük sayılabilecek bir kısmı $(\% 5,6)$ bulut bilişimi uyguladığını, bunun yanında çoğunlukla $(\% 75,4)$ bulut bilişimi uygulamayı henüz düşünmediklerini belirtmişlerdir (Tablo 8). Bulut bilişimi “deneme" safhasında da olsa uygulamayı düşünenlerin oranının oldukça düşük düzeylerde $(\% 4,0)$ olması da dikkat çekicidir. Elde edilen veriler Türkiye üniversite kütüphanelerinde bulut bilişim uygulama düzeyinin oldukça düşük sayılabilecek seviyelerde olduğu yönündedir. Kütüphanelerde bulut bilişim uygulama düzeyinin bu denli düşük olmasının ardında yatan nedenlerin en önemlilerinden bir tanesinin kütüphanelerin bulut bilişim farkındalığının yeterli seviyelerde olmaması gösterilebilir. Devlet ve vakıf üniversite kütüphanelerine göre uygulama düzeyleri arasında anlamlı bir fark olup olmadığını belirlemek için yapılan ki-kare testinde anlamlı bir fark olmadığ $(\chi 2=0,340)$ anlaşılmıştır.

Tablo 8: Bulut Bilişim Uygulama Durumu

\begin{tabular}{l|l|l}
\hline \multicolumn{1}{c|}{ Uygulama Durumu } & \multicolumn{1}{c|}{$\mathrm{n}$} & \multicolumn{1}{c}{$\%$} \\
\hline Uygulama & 7 & 5,6 \\
\hline Deneme & 5 & 4,0 \\
\hline Planlama & 19 & 15 \\
\hline Düşünülmüyor. & 95 & 75,4 \\
\hline Toplam & 126 & 100,0 \\
\hline
\end{tabular}

Kütüphanelere genel bulut uygulamaları kullanım durumları da sorulmuştur (Tablo 9). Kütüphaneler en yüksek oranda $(\% 59,5)$ "sosyal ağları", en düşük oranda ise ofis uygulamaları $(\% 11,1)$ bulut ortamında kullandıklarını belirtmişlerdir. Bu durumu azalan oranda \%42,1 ile "e-posta", \%39,7 ile "dosya paylaşımı", \%38,9 ile "bilgi toplama", \%30,2 ile "fotoğraf paylaşım", \%27,8 ile "video paylaşım", \%15,1 ile "veri depolama", \%11,9 ile "forum", \%11,1 ile "işletim sistemi, \%12,7 ile "ofis uygulamaları" kullanımı izlemektedir. Elde edilen bulgular Türkiye üniversite kütüphanelerinin değişik bulut uygulamalarını (e-posta, forum, sosyal ağ vb.) yaygın olarak kullanmadıklarını, ancak farkında olmasalar bile bulut bilişim uygulamalarını çoktan kullanmaya başladıklarını göstermektedir.

Tablo 9: Genel Bulut Uygulamaları Kullanımı

\begin{tabular}{|c|c|c|c|c|c|c|c|c|c|c|}
\hline \multirow{2}{*}{ Değişken Düzeyi } & \multicolumn{2}{|c|}{ Planlama } & \multicolumn{2}{|c|}{ Deneme } & \multicolumn{2}{|c|}{ Uygulama } & \multicolumn{2}{|c|}{ Mevcut değil } & \multicolumn{2}{|c|}{ Toplam } \\
\hline & $\mathrm{n}$ & $\%$ & $\mathrm{n}$ & $\%$ & $\mathrm{n}$ & $\%$ & $\mathrm{n}$ & $\%$ & $\mathrm{n}$ & $\%$ \\
\hline E-posta & 3 & 2,4 & 2 & 1,6 & 53 & 42 & 68 & 54,0 & 126 & 100,0 \\
\hline Forum & 9 & 7,1 & 3 & 2,4 & 15 & 11,9 & 99 & 78,6 & 126 & 100,0 \\
\hline Sosyal A $\breve{g}$ & 2 & 1,6 & 4 & 3,2 & 75 & 59,5 & 45 & 35,7 & 126 & 100,0 \\
\hline Bilgi Toplama & 2 & 1,6 & 7 & 5,5 & 49 & 38,9 & 68 & 54,0 & 126 & 100,0 \\
\hline Dosya Paylaşımı & 18 & 14,3 & 17 & 13,5 & 50 & 39,7 & 41 & 32,5 & 126 & 100,0 \\
\hline Video Paylaşımı & 4 & 3,2 & 6 & 4,8 & 35 & 27,8 & 81 & 64,2 & 126 & 100,0 \\
\hline Foto Paylaşımı & 4 & 3,2 & 8 & 6,3 & 38 & 30,2 & 76 & 60,3 & 126 & 100,0 \\
\hline Veri Paylaşımı & 4 & 3,2 & 4 & 3,2 & 19 & 15,1 & 99 & 78,6 & 126 & 100,0 \\
\hline İşletim Sistemi & 4 & 3,2 & 1 & 0,8 & 16 & 12,7 & 105 & 83,3 & 126 & 100,0 \\
\hline Ofis Uygulamaları & 10 & 7,9 & 6 & 4,8 & 14 & 11,1 & 96 & 76,2 & 126 & 100,0 \\
\hline
\end{tabular}

Kütüphanelere kütüphanecilik alanına yönelik bulut uygulamalarını kullanım durumları da sorulmuştur. Kütüphaneler en yüksek oranda \%40,5 ile "web keşif araçlarını", en düşük oranda ise "araştırma rehberlerini” (\%19,0) kullandıklarını belirtmişlerdir (Tablo 10). Bu durumu \%29,4 ile "elektronik kaynak yönetim sistemleri”, \%27,8 ile "dijital varlık yönetim sistemi”, \%26,2 ile "web sayfası" ve "açık arşiv", \%23,0 ile "tarama (OPAC)", \%22,2 ile "otomasyon”, \%21,4 ile "sunucu”, \%20,6 ile

48 I $P$ a g e

www.iiste.org 
"URL" ve \%19,0 ile "araştırma rehberleri" izlemektedir. Araştırma neticesinde elde veriler kütüphanelerin kütüphanecilik alanına yönelik uygulamaları (dijital varlık yönetim sistemleri, tarama (OPAC) vb.) bulut ortamında kullanma oranlarının düşük sayılabilecek düzeylerde olduğunu ve Türkiye üniversite kütüphanelerinde bulut uygulamalarının yaygın olarak kullanılmadığını ortaya koymaktadır.

Tablo 10: Bulutta Kütüphane Hizmetleri Kullanımı

\begin{tabular}{l|rr|rr|rr|rr}
\hline \multirow{2}{*}{ Değişken Düzeyi } & \multicolumn{3}{c|}{ (1) } & \multicolumn{2}{c|}{ (2) } & \multicolumn{2}{c|}{ (3) } & \multicolumn{2}{c}{ (4) } \\
\cline { 2 - 11 } & \multicolumn{2}{|c|}{$\mathrm{n}$} & $\%$ & $\mathrm{n}$ & $\%$ & $\mathrm{n}$ & $\%$ & \multicolumn{2}{c}{$\mathrm{n}$} & $\%$ \\
\hline Dijital Varlık Yönetim Sistemleri & 35 & 27,8 & 49 & 38,9 & 42 & 33,3 & 126 & 100,0 \\
\hline Web Keşif Araçları & 51 & 40,5 & 41 & 32,5 & 34 & 27,0 & 126 & 100,0 \\
\hline Elektronik Kaynak Yönetim Sistemleri & 37 & 29,4 & 55 & 43,7 & 34 & 27,0 & 126 & 100,0 \\
\hline Otomasyon Sistemleri & 28 & 22,2 & 77 & 61,1 & 21 & 16,7 & 126 & 100,0 \\
\hline Sunucular & 27 & 21,4 & 84 & 66,7 & 15 & 11,9 & 126 & 100,0 \\
\hline Web Sayfası & 33 & 26,2 & 49 & 38,9 & 44 & 34,9 & 126 & 100,0 \\
\hline Tarama (OPAC) & 29 & 23,0 & 66 & 52,4 & 31 & 24,6 & 126 & 100,0 \\
\hline URL Uygulamaları & 26 & 20,6 & 87 & 69,0 & 13 & 10,3 & 126 & 100,0 \\
\hline Araştırma Rehberleri & 24 & 19,0 & 84 & 66,7 & 18 & 14,3 & 126 & 100,0 \\
\hline Açık Arşiv Uygulamaları & 33 & 26,2 & 63 & 50,0 & 30 & 23,8 & 126 & 100,0 \\
\hline
\end{tabular}

(1)Bulutta mevcut, (2)Mevcut, bulut değil, (3)Mevcut değil, (4)Toplam

Kütüphanelerin çoğunluğu $(\% 77,0)$ bulut bilişim mimarisine sahip olmadıklarını belirtmişlerdir (Tablo 11). Bu durumu azalan oranda \%10,3'ü “özel bulut”, \%9,5'u "genel bulut”, \%2,4'ü “hibrit bulut", \%0,8'i "topluluk bulutu" mimarisi izlemektedir. Elde edilen veriler Türkiye üniversite kütüphanelerinde genelde bir bulut bilişim mimarisinin bulunmadığı yönündedir. $\mathrm{Bu}$ sonuç kütüphanelerin çoğunluğunun bulut bilişimi çoğunlukla uygulamayı düşünmediklerine ilişkin sonucu da desteklemektedir. Devlet ve vakıf üniversite kütüphanelerine göre bulut mimari durumunda anlamlı bir fark olup olmadığını belirlemek için ki-kare testinde anlamlı bir fark olmadığı $(\chi 2=0,768)$ anlaşılmıştır.

Tablo 11: Bulut Bilişim Mimari Durumu

\begin{tabular}{l|l|l}
\hline \multicolumn{1}{c|}{ Mevcut Mimari } & \multicolumn{1}{c|}{$\mathrm{n}$} & \multicolumn{1}{c}{$\%$} \\
\hline Özel Bulut & 13 & 10,3 \\
\hline Topluluk Bulutu & 1 & 0,8 \\
\hline Hibrit (melez) Bulut & 3 & 2,4 \\
\hline Genel Bulut & 12 & 9,5 \\
\hline Mevcut değil. & 97 & 77,0 \\
\hline Toplam & 126 & 100,0 \\
\hline
\end{tabular}

\subsection{Buluta Geçiş Hazırlık Durum ve Düzeyi}

Araştırmaya katılan kütüphaneler çoğunlukla $(\% 65,1)$ bulut tabanlı kütüphane otomasyonu kullanmadıklarını belirtmişlerdir (Tablo 12). Elde edilen veriler araştırmaya katılan kütüphanelerin kullandıkları kütüphane otomasyonları açısından olanakları itibariyle bulut bilişime geçişe yeterince hazır olmadıklarını ortaya koymaktadır. Devlet ve vakıf üniversite kütüphanelerine göre bulut tabanlı otomasyon kullanımında anlamlı bir fark olup olmadığını belirlemek için yapılan ki-kare testinde anlamlı bir fark $(\chi 2=0,585)$ olmadığı görülmüştür. 
Tablo 12: Bulut Tabanlı Otomasyon Kullanımı

\begin{tabular}{|c|c|c|c|}
\hline Değişkenler & Değişken Düzeyi & $\mathrm{n}$ & $\%$ \\
\hline \multirow{4}{*}{$\begin{array}{l}\text { Bulut Tabanlı } \\
\text { Otomasyon Durumu }\end{array}$} & Bulut & 28 & 22,2 \\
\hline & Bulut değil & 82 & 65,1 \\
\hline & Cevapsiz & 16 & 12,7 \\
\hline & Toplam & 126 & 100,0 \\
\hline
\end{tabular}

Araştırma kapsamında kütüphanelere sunucu işletip işletmedikleri de sorulmuştur. Elde edilen veriler kütüphanelerin yaklaşık üçte birinin $(\% 29,4)$ kendi kütüphanecilik faaliyetlerinin yanında ayrıca teknik bilgi ve donanım gerektiren sunucu işletme BİT faaliyeti ile de uğraştıklarını göstermektedir (Tablo 13). Devlet ve vakıf üniversite kütüphanelerine göre sunucu işletiminde anlamlı bir fark olup olmadığını belirlemek için yapılan ki-kare testinde anlamlı bir fark $(\chi 2=0,268)$ olmadığ 1 görülmüştür.

Tablo 13: Sunucu İşletme Durumu

\begin{tabular}{l|l|l}
\hline \multicolumn{1}{c|}{ Sunucu İşletme Durumu } & \multicolumn{1}{c|}{$\mathrm{n}$} & \multicolumn{1}{c}{$\%$} \\
\hline Evet & 37 & 29,4 \\
\hline Hayır & 89 & 70,6 \\
\hline Toplam & 126 & 100,0 \\
\hline
\end{tabular}

Sunucu işlettiğini belirten kütüphanelerin çoğunluğu $(\% 64,8)$ sanallaştırma teknolojisini kullandığını belirtmiştir (Tablo 14). Yönetim ve maliyet açısından önemli avantajlar sağlayan sanallaştırma teknolojisinin bulut bilişime hazır olma ve geçiş adımı olduğu göz önüne alındığında elde edilen veriler sunucu işlettiğini belirten kütüphanelerin çoğunlukla bu teknolojiyi kullandıklarını göstermektedir. Ancak bu durum kütüphanelerin kendi faaliyetleri yanında ayrıca BİT kullanımına ilişkin yeterli düzeyde teknik bilgiye sahip olmalarını gerektirmektedir. Araştırmaya katılan devlet ve vakıf üniversite kütüphaneleri arasında sanallaştırma teknolojisinin kullanımında anlamlı bir fark olup olmadığını belirlemek için \%95 güven aralığında yapılan ki-kare testinde anlamlı bir fark $(\chi 2=0,168)$ olmadığ anlaşılmıştır.

Tablo 14: Sanallaştırma Kullanımı

\begin{tabular}{|c|c|c|}
\hline Sanal Teknoloji Kullanımı & $\mathrm{n}$ & $\%$ \\
\hline Evet & 24 & 64,8 \\
\hline Hayır & 13 & 35,2 \\
\hline Toplam & 37 & 100,0 \\
\hline
\end{tabular}

Tablo 15'de sunulan veriler katılımcıların çoğunluğunun $(\% 75,9)$ kütüphane hizmetlerinde bulut bilişim hizmet modelinin geleceği olduğuna inandıklarını, yaklaşık üçte birinin $(\% 35,2)$ bulut bilişim konusunda üst yönetimin desteğinin yeterli olmadığını değerlendirdikleri, yaklaşık üçte birinin $(\% 35,2)$ bilişim teknolojileri yatırımlarında bulut bilişim uyumluluğuna dikkat edilmediğini belirtmişlerdir.

Tablo 15: Kütüphane Hizmetlerinde Bulut Bilişimin Geleceği

\begin{tabular}{|c|c|c|c|c|c|c|c|c|}
\hline \multirow{2}{*}{ Değişkenler } & \multicolumn{2}{|c|}{ Katılmiyorum } & \multicolumn{2}{|c|}{ Kararsızım } & \multicolumn{2}{|c|}{ Katıliyorum } & \multicolumn{2}{|c|}{ Toplam } \\
\hline & $\mathrm{n}$ & $\%$ & $\mathrm{n}$ & $\%$ & $\mathrm{n}$ & $\%$ & $\mathrm{n}$ & $\%$ \\
\hline Bulut Bilişimin Geleceği & 9 & 8,3 & 17 & 15,7 & 82 & 75,9 & 108 & 100,0 \\
\hline Üst Yönetim Desteği & 38 & 35,2 & 41 & 38,0 & 29 & 26,9 & 108 & 100,0 \\
\hline Bulut Uyumluluğu & 38 & 35,2 & 44 & 40,7 & 26 & 24,1 & 108 & 100,0 \\
\hline
\end{tabular}

$\mathbf{5 0 |}$ | P a g e 
Araştırmada kütüphanelere olası bir Bulut Üst Kurul (BÜK) yapılanması durumu da sorulmuştur. Kütüphanelerin büyük çoğunluğu $(\% 84,9)$ olası bir BÜK yapılanmasını desteklediklerini belirtmişlerdir (Tablo 16). Kütüphaneler en yüksek oranda \%40,5 ile "TÜBİTAK" bünyesinde oluşturulmasını desteklerini belirtmişlerdir (Tablo 13). Bu durumu azalan oranda \%16,7 ile "üniversiteler ortaklaşa" ve "devlet ve özel sektör", \%18,3 ile "YÖK", \%7,9 ile "YÖK harici Kamu Kurumu" izlemektedir. Kütüphanelerin ilk sırada TÜBİTAK' 1 tercih etmelerinin nedenleri arasında bu kurum tarafindan ulusal kapsamda bilgi/belge hizmetlerinin sunulması, akademik bilgiye erişimde farklı çözümler üretilmesi, ULAKBİM-EKUAL kapsamında Türkiye'deki akademik bilgi kullanımının teşvik edilmesi sayılabilir. Devlet ve vakıf üniversite kütüphanelerine göre BÜK yapılanmasına destek verilmesinde $(\chi 2=0,218)$ yapılan ki-kare testinde anlamlı bir fark bulunamamıştır.

Tablo 16: Bulut Üst Kurul (BÜK) Yapılanması

\begin{tabular}{c|l|l|l}
\hline \multicolumn{1}{c|}{ Değişkenler } & \multicolumn{1}{|c|}{ Değişken Düzeyi } & \multicolumn{1}{c|}{$\mathrm{n}$} & \multicolumn{1}{c}{$\%$} \\
\hline \multirow{4}{*}{ BÜK Yapılanması Talebi } & Evet & 107 & 84,9 \\
\cline { 2 - 4 } & Hayır & 19 & 15,1 \\
\cline { 2 - 4 } & Toplam & 126 & 100,0 \\
\hline & YÖK & 23 & 18,3 \\
\cline { 2 - 4 } & YÖK harici & 10 & 7,9 \\
\cline { 2 - 4 } BÜK Sorumluluğu & Ünv.ler ortak & 21 & 16,7 \\
\cline { 2 - 4 } & TÜBİTAK & 51 & 40,5 \\
\cline { 2 - 4 } & Devlet\&Özel & 21 & 16,7 \\
\cline { 2 - 4 } & Toplam & 126 & 100,0 \\
\hline
\end{tabular}

Kütüphaneler olası bir BÜK yapılanmasının en yüksek oranda \%84,1 ile "bulut bilişimin kütüphanelerde kullanımına yönelik politika geliştirilmesi" ve "kütüphane bulut uygulamaları konusunda Ar-Ge çalışmaları yapılması" faaliyetlerine öncelik vermesi gerektiğini ifade etmişlerdir (Tablo 17). Bu durum kütüphane hizmetlerinin bulutta sunulabilmesi için strateji ve/veya politikalar geliştirilmesi gerekliliğini ortaya koymaktadır.

Tablo 17: Bulut Üst Kurulu (BÜK) Öncelikleri

\begin{tabular}{|c|c|c|c|c|c|c|c|c|}
\hline \multirow{2}{*}{ Değişkenler } & \multicolumn{2}{|c|}{ Katılmiyorum } & \multicolumn{2}{|c|}{ Kararsızım } & \multicolumn{2}{|c|}{ Katıliyorum } & \multicolumn{2}{|c|}{ Toplam } \\
\hline & $\mathrm{n}$ & $\%$ & $\mathrm{n}$ & $\%$ & $\mathrm{n}$ & $\%$ & $\mathrm{n}$ & $\%$ \\
\hline Ulusal politikalar geliştirilmesi & 16 & 12,7 & 11 & 8,7 & 99 & 78,6 & 126 & 100,0 \\
\hline Ktph. Politikaları & 12 & 9,5 & 8 & 6,3 & 106 & 84,1 & 126 & 100,0 \\
\hline Farkındalık & 11 & 8,7 & 10 & 7,9 & 105 & 83,3 & 126 & 100,0 \\
\hline Veri güvenliği ve gizliliği & 11 & 8,7 & 27 & 21,4 & 88 & 69,8 & 126 & 100,0 \\
\hline Ar-Ge çalışmaları & 11 & 8,7 & 9 & 7,1 & 106 & 84,1 & 126 & 100,0 \\
\hline
\end{tabular}

Araştırmaya katılanların çoğunluğu $(\% 79,4)$ bir bulut çalışma grubu oluşturulması durumunda katılmak istediklerini belirtmişlerdir (Tablo 18). Bu durum kütüphane hizmetlerinin bulutta sunulmasının desteklendiğinin bir göstergesi olarak öngörülebilir. Bulgular her ne kadar kütüphanelerin buluta geçişe hazır olmadıklarını ortaya koysa da kütüphanelerin bulutu benimseme eğiliminde olduklarını da ortaya koymaktadır. 
Tablo 18: Bulut Çalışma Grubuna Katılımı

\begin{tabular}{l|l|l}
\hline \multicolumn{1}{c|}{ Bulut Çalışma Grubuna Katılım İsteği } & \multicolumn{1}{|c|}{$\mathrm{n}$} & \multicolumn{1}{c}{$\%$} \\
\hline Evet & 100 & 79,4 \\
\hline Hayır & 26 & 20,6 \\
\hline Toplam & 126 & 100,0 \\
\hline
\end{tabular}

Kütüphanelere kütüphane otomasyon sistemlerinin işletmesi faaliyetini kendileri dışında başka bir kuruma verilmesine izin verip vermeyecekleri de sorulmuştur. Cevaplar değerlendirildiğinde, çoğunluğun $(\% 61,1)$ halen kullanmakta oldukları kütüphane otomasyonlarının üniversiteleri dışında bir kuruluş tarafından işletilmesine izin vermeyecekleri durumunu ortaya koymaktadır (Tablo 19).

Tablo 19: Kütüphane Otomasyonu İşletim İzin Verme Durumu

\begin{tabular}{l|l|c}
\hline \multicolumn{1}{c|}{ Otomasyon İşletimine İzin Verme Durumu } & $\mathrm{n}$ & $\%$ \\
\hline Evet & 49 & 38,9 \\
\hline Hayır & 77 & 61,1 \\
\hline Toplam & 126 & 100,0 \\
\hline
\end{tabular}

Bu durumun nedeni sorulduğunda en yüksek oranda \%54,8 ile "hizmet sağlayıcısına bağımlılık" nedeni belirtilmiştir (Tablo 20). Bu durumu azalan oranda \%54,0 ile "yasal sorumlulukların belirsizliği" ve "veri güvenliği/gizliliği”, \%52,4 ile "hizmet kalitesinin öngörülemez olması", \%48,0 ile "yazılım güvenliği”, \%46,0 ile "birlikte çalışabilirlik", \%40,8 ile "internet bağlantı hızı" ve \%38,9 ile "internet bağlantı maliyeti” izlemektedir. Elde edilen veriler kütüphane bulut hizmetlerinin her bir kütüphaneye ait BİT kaynakları tarafından sunulmasının ve bu BITT kaynakların her bir kütüphaneye has olmasının tercih edildiği yönünde olduğu şeklinde değerlendirilebilir.

Tablo 20: Kütüphane Otomasyonu İzni

\begin{tabular}{|c|c|c|c|c|c|c|c|c|}
\hline \multirow{2}{*}{ Değişkenler } & \multicolumn{2}{|c|}{ Katılmiyorum } & \multicolumn{2}{|c|}{ Kararsızım } & \multicolumn{2}{|c|}{ Katıliyorum } & \multicolumn{2}{|c|}{ Toplam } \\
\hline & $\mathrm{n}$ & $\%$ & $\mathrm{n}$ & $\%$ & $\mathrm{n}$ & $\%$ & $\mathrm{n}$ & $\%$ \\
\hline Yazılım güvenliği & 27 & 21,6 & 38 & 30,4 & 60 & 48,0 & 126 & 100,0 \\
\hline Veri güv./gizliliğgi & 26 & 20,6 & 32 & 25,4 & 68 & 54,0 & 126 & 100,0 \\
\hline Internet h1z1 & 38 & 30,4 & 36 & 28,8 & 51 & 40,8 & 126 & 100,0 \\
\hline İnternet maliyeti & 39 & 31,0 & 38 & 30,2 & 49 & 38,9 & 126 & 100,0 \\
\hline Yasal sorumluluk & 25 & 19,8 & 33 & 26,2 & 68 & 54,0 & 126 & 100,0 \\
\hline Bağımlılık & 27 & 21,4 & 30 & 23,8 & 69 & 54,8 & 126 & 100,0 \\
\hline Hizmet kalitesi & 28 & 22,2 & 32 & 25,4 & 66 & 52,4 & 126 & 100,0 \\
\hline Birlikte çalışma & 28 & 22,2 & 40 & 31,8 & 58 & 46,0 & 126 & 100,0 \\
\hline
\end{tabular}

\subsection{Bulutta Kütüphane Hizmetleri}

Kütüphaneler çoğunlukla $(\% \mathbf{5 8 , 3 )}$ birinci sırada olarak "kütüphaneler arası işbirliği” hizmetinin buluta taşınması gerektiğini belirtmişlerdir (Tablo 21). Bu durumu azalan oranda \%56,5 ile "tarama ve OPAC", \%54,6 ile "kataloglama", \% 52,8 ile "dolaşım”, \% 50,0 ile "raporlama”, \%43,5 ile "sağlama", \%38,0 ile "danışma" bilgi hizmetleri izlemektedir. Elde edilen bulgular Türkiye üniversite kütüphanelerinin genelde kütüphane hizmetlerinin buluta taşınmasına destek verdiklerini ortaya koymaktadır. $\mathrm{Bu}$ soruya ilişkin bulguların değerlendirilmesinde bulut bilişim hakkında bilgi sahibi olduğunu belirten 108 adet kütüphanenin cevapları dikkate alınarak değerlendirmelerde bulunulmuştur. 
Tablo 21: Bulutta Kütüphane Hizmetleri

\begin{tabular}{|c|c|c|c|c|c|c|c|c|}
\hline \multirow{2}{*}{ Değişkenler } & \multicolumn{2}{|c|}{ Olmamalı } & \multicolumn{2}{|c|}{ Kararsızım } & \multicolumn{2}{|r|}{ Olmalı } & \multicolumn{2}{|c|}{ Toplam } \\
\hline & $\mathrm{n}$ & $\%$ & $\mathrm{n}$ & $\%$ & $\mathrm{n}$ & $\%$ & $\mathrm{n}$ & $\%$ \\
\hline Sağlama & 35 & 32,4 & 26 & 24,1 & 47 & 43,5 & 108 & 100,0 \\
\hline Kataloglama & 30 & 27,8 & 19 & 17,6 & 59 & 54,6 & 108 & 100,0 \\
\hline Danışma & 32 & 29,6 & 35 & 32,4 & 41 & 38,0 & 108 & 100,0 \\
\hline Dolaşım & 32 & 29,6 & 19 & 17,6 & 57 & 52,8 & 108 & 100,0 \\
\hline Tarama ve OPAC & 40 & 37,0 & 7 & 6,5 & 61 & 56,5 & 108 & 100,0 \\
\hline İşbirliği & 32 & 29,6 & 13 & 12,0 & 63 & 58,3 & 108 & 100,0 \\
\hline Raporlama & 26 & 24,1 & 28 & 25,9 & 54 & 50,0 & 108 & 100,0 \\
\hline
\end{tabular}

\subsection{Buluta Geçiş Fayda ve Sorunları}

Kütüphaneler bulutun en önemli faydası olarak büyük çoğunlukla $(\% 93,5)$ "hizmet çeşitliliğini" belirtmişlerdir (Tablo 22). Bu durumu azalan oranda \%86,1 ile "hizmetlerde esneklik", \%84,3 ile "kütüphane hizmetlerinin daha basit BİT araçlarıyla yürütülmesi", \%83,3 ile "doğal afetlerde ve beklenmeyen gelişmelerde hizmet sürekliliği" ve "kütüphaneler aras1 işbirliğinin gelişmesine katkı", \%71,3 ile "bilgi teknolojilerinin çevreye zararının azalacă̆ı", \%68,5 ile "BİT işletim ve bakım harcamalarının düşeceği”, \%63,9 ile "hizmetlerde kullanıldığı kadar ödeme", \%47,2 ile "BİT faaliyetlerine daha az bağımlılık" seçenekleri izlemektedir. Elde edilen veriler Türkiye üniversite kütüphanelerinin bulut bilişimin beraberinde getireceği sorunlarına rağmen genelde faydalarına katılım sağladıklarını ortaya koymaktadır. Bu soruya ilişkin bulguların değerlendirilmesinde bulut bilişim hakkında bilgi sahibi olduğunu belirten 108 adet kütüphanenin cevapları dikkate alınarak değerlendirmelerde bulunulmuştur.

Tablo 22: Bulut Bilişim Faydaları

\begin{tabular}{|c|c|c|c|c|c|c|c|c|}
\hline \multirow{2}{*}{ Değişkenler } & \multicolumn{2}{|c|}{ Katılmiyorum } & \multicolumn{2}{|c|}{ Kararsızım } & \multicolumn{2}{|c|}{ Katıliyorum } & \multicolumn{2}{|c|}{ Toplam } \\
\hline & $\mathrm{n}$ & $\%$ & $\mathrm{n}$ & $\%$ & $\mathrm{n}$ & $\%$ & $\mathrm{n}$ & $\%$ \\
\hline Daha az BİT Harcaması & 9 & 8,3 & 25 & 23,1 & 74 & 68,5 & 108 & 100,0 \\
\hline Hizmet Çeşitliliğgi & 2 & 1,9 & 5 & 4,6 & 101 & 93,5 & 108 & 100,0 \\
\hline Hizmet Esnekliği & 6 & 5,6 & 9 & 8,3 & 93 & 86,1 & 108 & 100,0 \\
\hline Hizmet Sürekliliği & 7 & 6,5 & 11 & 10,2 & 90 & 83,3 & 108 & 100,0 \\
\hline Kütüphaneler Arası İşbirliği & 3 & 2,8 & 15 & 13,9 & 90 & 83,3 & 108 & 100,0 \\
\hline Daha Az BİT Bağımlılı̆̆1 & 21 & 19,4 & 36 & 33,3 & 51 & 47,2 & 108 & 100,0 \\
\hline Daha Basit BİT Araçları & 7 & 6,5 & 10 & 9,3 & 91 & 84,3 & 108 & 100,0 \\
\hline Çevreye Daha Az Zarar & 6 & 5,6 & 25 & 23,1 & 77 & 71,3 & 108 & 100,0 \\
\hline Kullandığın Kadar Öde & 6 & 5,6 & 33 & 30,6 & 69 & 63,9 & 108 & 100,0 \\
\hline
\end{tabular}

Kütüphaneler çoğunlukla $(\% 65,7)$ "hizmet sağlayıcıya bağımlılı̆̆ı" sorun olarak birinci sırada belirtmişlerdir (Tablo 23). Bu durumu azalan oranda \%57,4 ile "mevzuat" ve "veri güvenliği ve gizliliği", \%54,6 ile "bilgi işlem kaynakları", \%49,1 ile "yönetim desteği”, \%47,2 ile "insan kaynakları", \%41,7 ile "birlikte çalışabilirlik", \%40,7 ile "maliyet", \%39,8 ile "farkındalık" seçenekleri izlemektedir. Elde edilen bulgular Türkiye üniversite kütüphanelerinin bulut bilişimin faydaları yanında beraberinde getireceği sorunlar olacağına genelde katılım sağladıklarını ortaya koymaktadır. Bu soruya ilişkin bulguların değerlendirilmesinde bulut bilişim hakkında bilgi sahibi olduğunu belirten 108 adet kütüphanenin cevapları dikkate alınarak değerlendirmelerde bulunulmuştur. 
Tablo 23: Bulut Bilişim Sorunları

\begin{tabular}{|c|c|c|c|c|c|c|c|c|}
\hline \multirow{2}{*}{ Değişkenler } & \multicolumn{2}{|c|}{ Katılmiyorum } & \multicolumn{2}{|c|}{ Kararsızım } & \multicolumn{2}{|c|}{ Katıliyorum } & \multicolumn{2}{|c|}{ Toplam } \\
\hline & $\mathrm{n}$ & $\%$ & $\mathrm{n}$ & $\%$ & $\mathrm{n}$ & $\%$ & $\mathrm{n}$ & $\%$ \\
\hline Veri Güvenliği ve Gizliliği & 16 & 14,8 & 30 & 27,8 & 62 & 57,4 & 108 & 100,0 \\
\hline Birlikte Çalışabilirlik & 28 & 25,9 & 35 & 32,4 & 45 & 41,7 & 108 & 100,0 \\
\hline Farkındalık & 31 & 28,7 & 34 & 31,5 & 43 & 39,8 & 108 & 100,0 \\
\hline Mevzuat & 11 & 10,2 & 35 & 32,4 & 62 & 57,4 & 108 & 100,0 \\
\hline Maliyet & 24 & 22,2 & 40 & 37,0 & 44 & 40,7 & 108 & 100,0 \\
\hline Yönetim Desteği & 20 & 18,5 & 35 & 32,4 & 53 & 49,1 & 108 & 100,0 \\
\hline İnsan Kaynakları & 22 & 20,4 & 35 & 32,4 & 51 & 47,2 & 108 & 100,0 \\
\hline Bilgi İşlem Kaynakları & 25 & 23,1 & 24 & 22,2 & 59 & 54,6 & 108 & 100,0 \\
\hline Hizmet Sağlayıcı Bağımlılığı & 9 & 8,3 & 28 & 25,9 & 71 & 65,7 & 108 & 100,0 \\
\hline
\end{tabular}

\section{Sonuç ve Öneriler}

Araştırma kapsamında elde edilen sonuçlar; "Bulut Bilişim Farkındalığı”, "Bulut Bilişim Gereksiniminin Varlığı ve Düzeyi”, "Bulut Uygulamalarının Kullanım Durumu”, "Buluta Geçiş Hazırlık Durumu ve Düzeyi”, "Buluta Geçiş Fayda ve Sorunları" başlıkları altında aşağıda sunulmuştur:

- Bulut Bilişim Farkındalığı: Kütüphanelerin çoğunluğunun $(\% 68,2)$ bulut bilişim bilgi düzeyi yeterli seviyede değildir. Sayıları az olsa da bulut bilişimden hiç haberi olmayan kütüphaneler vardır. Kütüphaneler bulut bilişim bilgisini edinebilecekleri bilgi edinme ortamlarından yeterince faydalanmamakta, bu durum kütüphanelerde bulut bilişim hizmet modelinden yararlanılmasını olumsuz olarak etkilemektedir. Kütüphanelerin bulut bilişim bilgisini üst yönetimden edinme oranları diğer bilgi edinme ortamlarına nazaran oldukça düşük sayılabilecek bir düzeydedir. Kütüphaneler ulusal ve uluslararası bulut bilişim çalışmalarını yeterince takip etmemektedir.

- Bulut Bilişim Gereksiniminin Varlığg ve Düzeyi: Kütüphanelerin çoğunluğu BİT harcamalarını (işletme elektrik, yazılım, donanım ve personel) bütçelerinin yüksek maliyet oluşturan kalemleri arasında görmektedirler. Bulut bilişimden yararlanılmak istenmesinin arkasında esasen BİT kaynaklarının maliyet etkin kullanılmasının olduğu dikkate alındığında, bu sonuç bilgi hizmetlerinde bulut bilişime olan gereksinimin göstergesi şeklinde değerlendirilebilir. Kütüphanelerin büyük çoğunluğu bütçelerinin en yüksek harcama kalemi olarak "yazılım" harcamalarını görmektedirler. Bu sonuç öncelikle UHOS bulut hizmetlerinden yararlanılması gerekliliğini ortaya koymaktadır.

- Bulut Uygulamalarının Kullanım Durumu: Kütüphanelerin büyük çoğunluğu henüz bulutu uygulamayı düşünmemektedir. Bu sonuç kütüphanelerin çoğunluğunda bir bulut mimarisi bulunmamasına ilişkin sonucu da desteklemektedir. Kütüphanelerin bulut uygulamalarını kullanma oranları düşük sayılabilecek düzeylerdedir. Sonuçlar kütüphanelerde bulut uygulamalarının yaygın olarak kullanılmadığı yönündedir.

- Buluta Geçiş Hazırlık Durumu ve Düzeyi: Sunucu işleten kütüphanelerin çoğunluğu sanallaştırma teknolojisini kullanmaktadırlar. Sanallaştırma teknolojisinden yararlanmanın buluta hazır olma durumunda bir ön adım olduğu göz önüne alındığında bu durum olumlu gibi görünse de bu durum ayrıca kütüphanelerin BİT kullanımına ilişkin yeterli düzeyde teknik bilgiye sahip olmalarını gerektirmektedir. Kütüphanelerde oldukça düşük sayılabilecek düzeyde bulut tabanlı kütüphane otomasyonu kullanılmaktadır. Kütüphanelerin yaklaşık üçte ikisi otomasyonlarının üniversiteleri dışında başka bir kuruluş tarafından işletilmesine izin vermeyeceklerini belirtmişlerdir. $\mathrm{Bu}$ durum kütüphanelerin sahip oldukları yazılımlar itibariyle de bulut bilişime geçişe hazır olmadıkları sonucunu ortaya koymaktadır. Kütüphanelerin çoğunlukla $(\% 75,9)$ bulut uygulamalarının geleceği olduğunu düşünmelerine rağmen hem kütüphanelerde buluttan yararlanılması konusunda üst yönetimin desteğini yeterli seviyede $(\% 26,9)$ olmadığını düşünmeleri ve hem de kütüphane BİT yatırımlarında bulut

54 I P a g e 
bilişim uyumluluğunun yeterli düzeyde $(24,1)$ dikkate alınmadığını düşünmeleri buluta geçişe hazır olunmadığı sonucunu ortaya koymaktadır. Elde edilen bu sonuçlar kütüphanelerin buluta geçişe hazır olmadıklarını, ancak kütüphanelerin büyük çoğunluğun BÜK yapılanmasına destek verdiklerini, bulut bilişim hizmet modelinin geleceği olduğunu değerlendirdiklerini, oluşturulacak bir bulut bilişim çalışma grubuna katılmak istediklerini ve bulut bilişimi benimseme eğiliminde olduklarını ortaya koymaktadır.

- Buluta Geçiş Fayda ve Sorunları: Kütüphanelerin çoğunlukla $(\% 69,3)$ bulut bilişimin tüm faydalarına katıldıkları saptanmıştır. Elde edilen bu bulgular bulut bilişimin beraberinde getireceği sorunlara rağmen faydalarına katılım sağlandığı yönündedir.

- Araştırma sonuçları, kütüphane hizmetlerinin bulut ortamında yapılandırılması konusunda Türkiye üniversite kütüphanelerinde genelde bir gereksinimin varlığından söz edilebileceğini, ancak böyle bir oluşumun gerçekleştirilmesi yolunda kütüphanelerin hem iç dinamiklerinden hem de diş dinamiklerinden kaynaklanan çeşitli düzeylerde sorunların bulunduğunu ortaya koymaktadır.

- Türkiye üniversite kütüphanelerinde bulut bilişim hizmet modelinden faydalanılması konusunda var olan sorunların çözümüne yönelik öneriler aşağıda sunulmuştur:

- Son yıllarda üniversitelerin sayısında meydana gelen hızlı artış üniversite kütüphane sayısını da artırmıştır. Özellikle yeni kurulan üniversitelerdeki kütüphanelerin eşit imkânlara sahip olmayabilecekleri durumu bu kütüphanelerin kütüphane hizmetlerinin kalitesine ilişkin çeşitli soru işaretlerini akıllara getirebilir. Bulut bilişim, özellikle bütçeleri kısıtlı olan üniversite kütüphanelerinin bilişim teknolojilerine yönelik daha maliyet etkin bilişim teknolojileri yatırımlar yaparak bilgi hizmetlerini sunmalarına imkân sağlayacaktır. Bu bağlamda bulut bilişim hizmet modelinin üniversite kütüphanelerinde daha fazla yararlanılmasına ve yaygınlaştırılmasına yönelik hedefler içeren bir politika oluşturulmalı ve plan, program, bütçe ve uygulamaları ile bu durum desteklenmelidir. Araştırmada dünya kütüphanelerinde bulut bilişimin kullanımının teşvik edildiği anlaşılmaktadır. Türkiye'de kütüphanelerde bulut bilişim kullanımı teşvik edilerek bilgi hizmetlerinde başta maliyet etkinlik olmak üzere verimlilik artışı sağlanmalıdır.

- Çalışmanın bulgularında ortaya çıkan kütüphanelerin bulut bilişim farkındalığı artırılmalıdır. Farkındalık çalışmalarına ayrıca üniversite kütüphanelerine bilgi işlem desteği veren Bilgi İşlem Daire Başkanlıkları da dâhil edilmelidir. Bu çerçevede kütüphane personeline yönelik eğitim programları yapılandırılmalı, kütüphanecilerin bu konudaki ulusal ve uluslararası fuar, kongre, seminer vb. etkinliklere katılımları kolaylaştırılmalı ve desteklenmelidir.

- Başta kütüphanelerine bilgi işlem desteği veren Bilgi İşlem Daire Başkanlıkları olmak üzere ilgili firmalara ve girişimcilere kütüphanelerde bulut uygulamalarından çok daha fazla yararlanılması maksatlı gerekli teknik destek ve mali teşvikler sağlanmalıdır. Mevcut teknoloji geliştirme merkezleri de (teknokent, teknopark) kütüphane hizmetlerinin buluta taşınmasında değerlendirilmelidir. Çeşitli vergi muafiyetleri gibi destekleyici düzenlemelerle yatırımcılar, kişiler, kurumlar kütüphane hizmetlerinin bulut bilişim hizmet modelinden yararlanılarak sunulmasına özendirilmelidir. Devlet ve vakıf üniversite kütüphanelerini bünyesinde bulunduran çeşitli bulut projelerinin Devlet ve Özel Sektör eliyle başlatılması ve yürütülmesi teşvik edilmelidir. Söz konusu işletmelerin kütüphanelere bulut hizmet sağlayıcı olması durumunda Türkiye bulut bilişim pazarı büyüyerek ekonomiye katma değer sağlanabilecektir.

- Üniversite üst yönetimi tarafindan bilgi hizmetlerinin buluttan sunulmasının ve alınmasının önündeki problemlerin giderilmesi için kütüphane BİT yatırımlarında bulut uyumluluğu ve kullanımı teşvik edilmelidir.

- Türkiye'nin de üyesi olduğu OCLC'nin kütüphanelere maliyet etkinlik sunan, iş akışlarını daha etkin kılan ve üye kütüphaneler arasında veri ve iş paylaşımına imkân veren bulut tabanlı kütüphane yönetim uygulamalarının takip edilmesinde fayda bulunmaktadır.

- Hem Devlet ve hem de özel üniversite yönetimleri tarafindan kütüphanelere yönelik bulut çalışmalarına dayanan AR-Ge çalışma ve faaliyetlerine gerekli teknik ve mali destek verilmelidir. 
- Üniversitelerin Bilgi ve Belge Yönetimi bölümlerinde bulut bilişime ilişkin derslere yer verilmesi sağlanmalıdır. Bu bağlamda bu derslerin kapsamına Servis Odaklı Mimari (SOA), Bulut WEB Servisleri, WEB ve Mobil Programlama Dilleri, Dağıtık Veri Tabanı gibi bilişim konuları ile bulutta hizmete sunulan verilerin siber güvenliği konuları alınabilir. Yasal düzenlemeler kanalıyla üniversitelerin Bilgi ve Belge Yönetimi bölümlerinde görevli öğretim üyelerinin, kütüphanelerdeki her kademedeki yönetici ve çalışanların bir program çerçevesinde bulut bilişim eğitimi almaları sağlanmalı ve özellikle hizmet içi eğitimi destekleyecek tedbirler alınmalıdır.

- Üniversite kütüphanelerinin konsorsiyumlara üye olmaları ve bulut tabanlı kütüphane hizmetlerini bu yapılar üzerinden sunmaları teşvik edilmelidir.

- Bulut bilişimin kütüphaneler tarafından benimsenmesi ve etkin kullanılabilmesi Türkiye üniversite kütüphanelerinde İnternet ağ bağlantısının geniş bant erişiminin fiber teknoloji altyapısının yaygınlaşmasıyla doğrudan ilişkilidir. $\mathrm{Bu}$ nedenle yeni oluşturulan Türkiye üniversite kütüphaneleri dâhil tümüne geniş fiber İnternet erişimi sağlanmalıdır.

\section{References}

Abdu, H., Aliyu, A., Paulinus, U., Umar, M. (2017). "The Integration of Cloud Computing Technology in Academic Library Operations towards Effective Library Services". International Journal of Research in Science \& Engineering. Volume 3 Issue 1.

Akbaytürk, T., Sönmez, Ç., İsmail, Ç., Sami, Ç., Güssün, G., Gültekin, G., İlkay, H., Ebru, K., Ayhan, K. (2014). "2023'e Doğru Türkiye'de Üniversite Kütüphaneleri: Mevcut Durum, Sorunlar, Standartlar ve Çözüm Önerileri". Yükseköğretim Kurulu Üniversite Kütüphaneleri Çalışma Grubu, Ankara.

Al, U. (2002). "Üniversite kütüphanelerinde bilgi hizmetlerinin pazarlanması: Beytepe Merkez Kütüphanesi Örneği”. Yayımlanmamış Bilim Uzmanlığı Tezi. Hacettepe Üniversitesi, Ankara.

Aydın, H. (2017). "Üniversite kütüphaneleri ve bulut bilişim: Kavramsal bir model önerisi”. Yayımlanmamış Doktora Tezi. Hacettepe Üniversitesi, Ankara.

Bala, R. (2012). "How Cloud Computing Will Affect College Libraries". International Journal of Information Technology and Knowledge Management. Volume 5, No. 2, pp. 381-383.

Breeding, M. (2012). "Cloud Computing for Libraries". Journal of Electronic Resources Librarianship. Chicago, IL: ALA Techsource, (The Tech Set, 11), 121 pp. ISBN: 9781555707859.

Ogbu, C. ve Lawal, A. (2013). "Cloud Computing and Its Applications i -Library Services: Nigeria in Focus". International Journal of Innovation, Management and Technology. Vol. 4, No. 5, October 2013.

Hwang, K., Fox, G. ve Dongarra, J. (2012). "Distributed and Cloud Computing from Parallel Processing to the Internet of Things". Elsevier, Inc.

Clift, J. (2012). "Next Generation Library Management Systems and Electronic Resource Acquisitions". CAUL International Travelling Fellowship. 2012.

Çakın, İ. (1998). “Üniversitelerimizin bilgiye erişim ortamları: Genel değerlendirme”. Hacettepe Üniversitesi Edebiyat Fakültesi Dergisi: Cumhuriyetimizin 75. Yılı Özel Sayıs1, 1998: 37-67.

Çam, H. (2012). "Türkiye'deki Üniversitelerde Bulut Bilişim teknolojisinin Uygulanabilirliğinin Teknoloji Kabul Modeli Yaklaşımıyla Belirlenmesi". Yayınlanmamış Doktora Tezi, Atatürk Üniversitesi SBE.

56 | P a g e

www.iiste.org 
Yaşar, Ç. (2014). "Bulut Bilişim ve Örnek SaaS Uygulaması”. Yayımlanmamış Yükssek Lisans Tezi. Kırıkkale Üniversitesi Fen Bilimler Enstitüsü, Kırıkkale.

Çukadar, S., Gültekin, G., Sönmez, Ç. ve Kahvecioğlu, K. (2011). "Türkiye'de Üniversite Kütüphaneleri: Mevcut Durum ve Gelecek". Uluslararası Yükseköğretim Kongresi: Yeni Yönelişler ve Sorunlar (UYK-2011), İstanbul, Turkey, 27-29 May 2011. [Konferans bildirisi]

Dhamdhere, N. S. (2014). "Cloud Computing and Virtualization Technologies in Libraries". Hershey, PA: Information Science Reference.

Ertürk, E. ve Iles, H.R.E. (2015). "Case Study on Cloud Based Library Software as a Service: Evaluating EZproxy”. arXiv preprint arXiv:1511.07578.

Eyüpoğlu, Ç. (2013). "Bulut bilişim, geçiş ve Türkiye'deki mevcut durum”. Yüksek Lisans Tezi, Karadeniz Teknik Üniversitesi, Trabzon.

Gokul, A. ve Ambili K.S. (2014). "Cloud Computing and Its Application in Libraries".

Goldner, M. (2011). "Libraries and Cloud Computing". Product and Technology Advocate. Executive Director of Network Library Services. Winds of Change: Libraries and Cloud Computing. OCLC Online Computer Library Center, Inc.

Gosavi, N., Seetal, S.S. ve Dhakulkar, B. (2012). "Use of cloud computing in library and information science field”. International Journal of Digital Library Services. 2012:1(3).

Grant, C. (2012). "The Future of library systems. Information Standards Quarterly". Information Standards Quarterly. ISSN: 1041-0031. Fall 2012, v.24, no.4.

Han, Y. (2011). "Cloud computing: Case Studies and Total Costs of Ownership". Information Technology and Libraries, 2011: 30(4), 198-206.

Kaptan, S. (1995). "Bilimsel araştırma teknikleri ve istatistik yöntemleri”. Bilim Yayıncılık. Ankara: 1995.

Karadeniz, Ş. ve Y1lmaz, B. (2016). “Türkiye’nin 2015-2018 Bilgi Toplumu Stratejisi ve Eylem Planı'nda kütüphane kurumuna yaklaşım”. Türk Kütüphaneciliği Dergisi. 30(1), 59-83.

Kaushik, A. Kumar, A. (2013). "Application of Cloud Computing in Libraries". International Journal of Information Dissemination and Technology. 3(4), 270-273.

Kumar, D., Mangai, G. ve Ganesan, P. (2014). “A Perspective Study of Cloud Computing in Library Services”. Vol. 5(10), pp. 394-400. DOI: 10.5897/IJLIS2013.0367 ISSN 2141-2537.

Kumar, D. A. ve Mandal, S. (2013). "Development of cloud computing in integrated library management and retrieval system”. International Journal of Library and Information Science.

Henkoğlu, T. ve Külcü, Ö. (2013). "Bilgi Erişim Platformu Olarak Bulut Bilişim: Riskler ve Hukuksal Koşullar Üzerine Bir İnceleme”. Bilgi Dünyası. 2013:14 (1) 62-86.

Mirashe, P. S. ve Kalyankar, N.V. (2010). “Cloud Computing”. Journal of Computing. Volume 2, Issue 3, March 2010, ISSN 2151-9617.

National Institute of Standards and Technology (NIST). (2010). "Cloud Computing Reference Architecture". Recommendations of the National Institute of Standards and Technology. 
Okutucu, B. O. (2012). "Bulut Bilişim ve Teknolojileri”. Okan Üniversitesi, Fen Bilimleri Enstitüsü, Yüksek Lisans Tezi.

Özdaş, M. D. (2014). "Bulut Bilişimin Kamuda Kullanımı: Dünya Örnekleri ve Türkiye İçin Öneriler”. Uzmanlık Tezi.

Kumar, S.A. (2013). "Cloud computing for libraries: an economic strategy". In International Conference On Academic Libraries, India, 2013: 12th - 15th Feburary. [Konferans bildirisi]

Tavluoğlu, C. ve Korkmaz, A. (2014). "Danışma Hizmetlerinde Bulut Bilişim Uygulamalarının Kullanımı”. Bilgi Dünyası. 2014, 15 (2) 284-295. DOI: 10.15612/BD.2014.420.

Türk Standartları Enstitüsü (TSE) Bulut bilişim güvenlik ve kullanım standardı. (2013). https://tse.org.tr/IcerikDetay?ID=939\&ParentID=1202 adresinden erişim sağlanmıştır.

Vaughan, J. ve Costello, K. (2011). "Management and Support of Shared Integrated Library Systems". Information Technology \& Libraries. 30, no. 2 (2011): 62-70.

Wang, J. (2010). "From the Ground to the Cloud: A Practice at California State". CALA occsioanl paper series. California State University, East Bay.CALA OPS. 2010: (10), 1-8.

Yuvaraj, M. (2013). "Cloud Computing Applications in Indian Central University libraries: A study of librarians` use”. Library Philosophy and Practice (e-Journal). University of Nebraska.

Zimmer, M. (2015). "Privacy and cloud computing in public libraries: The case of BiblioCommons". iConference 2015 Proceedings. 2015. 